\title{
PENGARUH METODE TUTOR SEBAYA TERHADAP HASIL BELAJAR MAHASISWA PADA MATA KULIAH ANALISIS REAL
}

\author{
Darma Ekawati ${ }^{1}$, Karmila ${ }^{2}$ \\ Dosen Program Studi Pendidikan Matematika ${ }^{1,2}$ \\ Universitas Cokroaminoto Palopo \\ E-mail: darma.ekaa@gmail.com ${ }^{l}$
}

\begin{abstract}
ABSTRAK
Penelitian ini dilaksanakan di Universitas Cokroaminoto Palopo Untuk mengetahui hasil belajar mahasiswa pada Mata Kuliah Analisis Real dengan menggunakan model pembelajaran kooperatif dengan tutor sebaya. Penelitian ini adalah merupakan penelitian pre-eksperiman yang bertujuan untuk : (1) mengetahui hasil belajar mahasiswa pada matakuliah analisis real sebelum dan setelah diterapkan model pembelajaran kooperatif dengan tutor sebaya; (2) mengetahui peningkatan hasil belajar mahasiswa pada matakuliah analisis real setelah diterapkan model pembelajaran kooperatif dengan tutor sebaya. Instrumen pengumpulan data yang digunakan dalam penelitian ini berupa tes essai. Adapun populasi dalam penelitian ini adalah mahasiswa semester VI Program Studi Pendidikan Matematika Universitas Cokroaminoto Palopo Tahun Akademik 2015/2016. Hasil penelitian menunjukkan bahwa: (1) hasil belajar mahasiswa pada matakuliah analisis real sebelum di ajar menggunakan pembelajaran kooperatif dengan totur sebaya berada pada kategori rendah dengan nilai rata-rata 57.66; (2) hasil belajar mahasiswa pada matakuliah analisis real setelah diajar menggunakan pembelajaran kooperatif dengan totur sebaya berada pada kategori sedang dengan nilai rata-rata 78,875; (3) hasil belajar matematika mahasiswa pada matakuliah analisis real mengalami peningkatan setelah diajar dengan model pembelajaran kooperatif tutor sebaya; (4) peningkatan hasil belajar matematika mahasiswa pada matakuliah analisis real dihitung dengan rumus gain ternormalisasi sebesar 0.514 atau berada pada kategori sedang.
\end{abstract}

Kata Kunci: Hasil Belajar, Kooperatif, Tutor Sebaya.

\section{PENDAHULUAN}

Hasil belajar mahasiswa dapat dipengaruhi oleh beberapa faktor baik itu faktor dari dalam diri mahasiswa maupun dari luar diri mahasiswa. Salah satu kendala dalam pelaksanaan pembelajaran analisis real yang dialami oleh mahasiswa yaitu sikap negatif terhadap mata kuliah analisis real. Matakuliah analisis real seringkali menjadi momok yang cukup menakutkan di kalangan mahasiswa karena mata kuliah ini cukup ketat dalam memberlakukan sistem deduktif-aksiomatik dan hampir semua permasalahan di dalamnya bersifat pembuktian. Penentuan langkah-langkah pembuktian inilah yang sering dikeluhkan mahasiswa terutama dalam penentuan langkah awal pembuktian. Oleh sebab itu perlu penerapan metode, strategi dan model yang sesuai dalam mengajarkan mata kuliah analisis real. 
Salah satu kendala lain dalam pembelajaran adalah jumlah mahasiswa yang cukup banyak dalam satu kelas, fasilitas belajar yang kurang, kurangnya waktu dosen untuk membantu mahasiswa secara individu, adanya keengganan sebagian mahasiswa untuk bertanya pada dosen sehingga proses pembelajaran berlangsung kurang aktif, serta dosen kurang memanfaatkan mahasiswa untuk membantu temannya dalam belajar baik di dalam kelas maupun di luar kelas sebagai tutor.

Salah satu alternatif pemecahan dari permasalahan di atas adalah dengan menggunakan model pembelajaran dengan tutor sebaya (peer teaching). Metode tutor sebaya yaitu metode pembelajaran yang dilakukan dengan cara memberdayakan siswa yang memiliki daya serap tinggi dari kelompok siswa itu sendiri untuk menjadi tutor bagi teman-temannya, siswa yang menjadi tutor bertugas untuk memberikan materi belajar dan latihan kepada temannya-temannya yang belum faham terhadap materi atau latihan yang diberikan guru dilandasi aturan yang telah disepakati bersama dalam kelompok tersebut, sehingga akan terbangun suasana belajar kelompok yang bersifat kooperatif bukan kompetitif. Hubungan teman umumnya lebih dekat dibandingkan dengan hubungan dosen dengan mahasiswa, sehingga peran teman dapat mendukung adanya suatu motivasi tersendiri bagi anak (Ruseno Arjanggi, 2010).

Penerapan metode tutor sebaya mungkin dilakukan mengingat di dalam satu kelas mahasiswa mempunyai taraf kecerdasan yang heterogen, dimana terdapat mahasiswa yang pandai, sedang, dan kurang pandai. Mahasiswa yang pandai itulah yang difungsikan sebagai tutor sebaya. Metode belajar kelompok dengan tutor sebaya dapat diterapkan, karena ada kalanya mahasiswa lebih mudah menerima penjelasan yang diberikan oleh teman-teman sebayanya. Bantuan tutor sebaya ini, diharapkan nantinya mahasiswa dapat menanyakan hal-hal yang kurang dipahaminya, sampai mahasiswa tersebut benar-benar mengerti.

Tom V. Savage (Rusman, 2010) mengemukakan bahwa pembelajaran kooperatif adalah suatu pendekatan yang menekankan kerja sama dalam kelompok. Sedangkan, Trianto (2011:) mengemukakan bahwa pembelajaran kooperatif adalah pembelajaran yang muncul dari konsep bahwa siswa akan lebih mudah menemukan dan memahami konsep yang sulit jika mereka saling berdiskusi dengan temannya. Siswa secara rutin bekerja dalam kelompok untuk saling membantu memecahkan masalah-masalah kompleks.

Anita lie (Suprijono, 2010) mengungkapkan bahwa model pembelajaran kooperatif tidak sama dengan sekedar belajar dalam kelompok. Ada lima unsur dasar 
pembelajaran kooperatif yang membedakannya dengan pembagian kelompok asal-asalan. Pelaksanaan model pembelajaran kooperatif dengan benar akan menunjukkan pendidik mengelola kelas lebih efektif.

Roger dan David Johnson (Suprijono, 2010) mengungkapkan lima unsur dalam model pembelajaran kooperatif, yaitu

1. Positive interdependence (saling ketergantungan positif)

2. Personal responsibility (tanggung jawab perseorangan)

3. Face to face promotive interaction (interaksi promotif)

4. Interpersonal skill (komunikasi antar anggota)

5. Group processing (Pemrosesan kelompok)

Suprijono (2010:54) mengemukakan bahwa pembelajaran kooperatif adalah konsep yang elbih luas meliputi semua jenis kerja kelompok termasuk bentuk-bentuk yang lebih dipimpim oleh guru atau diarahkan oleh guru. Secara umum, pembelajaran kooperatif dianggap lebih diarahkan oleh guru, di mana guru menetapkan tugas dan pertanyaan-pertanyaan serta menyediakan bahan-bahan dan informasi yang dirancang untuk membantu siswa menyelesaikan masalah yang dimaksudkan.

Sutikno (2007) menyatakan bahwa untuk mencapai hasil belajar yang optimal, dianjurkan agar tenaga pengajar membiasakan diri menggunakan komunikasi banyak arah atau komunikasi sebagai transaksi, yakni tidak hanya melibatkan interaksi dinamis antara pendidik dengan siswa melainkan juga melibatkan interaksi antara siswa yang satu dengan siswa yang lainnya.

Abu ahmadi dan Widodo Supriyono (2013) menjelaskan bahwa tutor adalah siswa/mahasiswa yang sebaya yang ditunjuk/ditugaskan membantu teman yang mengalami kesulitan belajar. Dengan petunjuk-petunjuk dari dosen, tutor akan membantu temannya yang mengalami kesulitan. Tutor berperan sebagai pemimpin dalam kegiatan kelompok sebagai pengganti dosen.

Mulyadi (2008) mengemukakan bahwa untuk menentukan seorang siswa/mahasiswa layak atau tidak dijadikan tutor, maka mahasiswa tersebut harus memenuhi beberapa persyaratan menjadi tutor yaitu:

1. Mahasiswa yang tergolong prestasi belajarnya baik

2. Mempunyai hubungan sosial yang baik dengan teman-temannya

Djamarah (2010:25) juga mengemukakan bahwa dalam pemilihan dan penentuan 
siswa ataupun mahasiswa sebagai tutor sebaya diperlukan pertimbangan tersendiri. Seorang tutor belum tentu siswa yang paling pandai. Yang paling penting yang harus diperhatikan adalah

1. Dapat diterima oleh siswa sehingga mahasiswa yang lain tidak mempunyai rasa takut atau engan bertanya kepadanya

2. Dapat menerangkan/menjelaskan pelajaran yang dibutuhkan mahasiswa yang mendapat bantuan

3. Tidak tinggi hati, keras hati, dan sombong terhadap sesama kawan

4. Mempunyai daya kreativitas yang cukup untuk memberikan bimbingan, yaitu dapat menerangkan pelajaran kepada temannya.

Djamarah (2010) mengemukakan beberapa kelebihan pelaksanaan tutor sebaya, yaitu

1. Adalakanya lebih baik bagi beberapa anak yang mempunyai perasaan takut atau enggan bertanya kepada guru/dosennya

2. Bagi tutor, pekerjaan tutoring akan bermanfaat bagi dirinya sendiri untuk memperkuat konsep yang dibahas

3. Bagi tutor, hal ini merupakan kesempatan untuk melatih diri, memegang tanggung jawab dalam mengemban tugas dan melatih kesabaran

4. Mempererat hubungan antar sesama siswa sehingga mempertebal perasaan sosial Adapun kekurangan dari pelaksanaan tutor sebaya adalah:

1. Siswa yang dibantu seringkali belajar kurang serius karena merasa hanya berhadapan dengan temannya

2. Ada beberapa anak yang malu bertanya karena takut rahasianya diketahui oleh teman sebayanya

3. Bagi guru/dosen sulit menentukan tutor yang tepat bagi seseorang atau beberapa orang yang dibimbingnya

Melvin L. Siberman (2007) menjelaskan langkah-langkah dalam metode tutor sebaya adalah sebagai berikut:

1. Bagilah siswa/mahasiswa menjadi sub-sub kelompok. Buatlah sub-sub kelompok dengan jumlah siswa yang sesuai dengan topik yang akan diajarkan

2. Beri tiap kelompok sejumlah informasi, konsep, atau keterampilan untuk diajarkan kepada siswa lain. Topik yang diberikan kepada siswa harus saling berkaitan 
3. Perintahkan tiap kelompok untuk menyusun cara dalam menyajikan atau mengajarkan topik mereka kepada siswa lain. Sarankan mereka untuk menhindari cara mengajar sistem ceramah atau pembacaan laporan. DOronglah mereka untuk menjadikan pengalaman belajar sebagai pengalaman yang aktif bagi siswa.

4. Berikan waktu yang mencukupi untuk merencanakan dan mempersiapkannya (baik di dalam maupun di luar kelas). Kemudian perintahkan tiap kelompok untuk menyajikan pelajaran mereka.

\section{METODE PENELITIAN}

\section{A. Tempat dan Waktu}

Penelitian ini bertempat di Kampus III Universitas Cokroaminoto Palopo pada Program Studi Pendidikan Matematika pada kelas matakuliah analisis real. Adapun waktu pelaksanaan penelitian ini berlangsung selama 1 semester yaitu pada Semester Genap Tahun Akademik 2015/2016.

\section{B. Jenis dan Desain Penelitian}

Penelitian ini merupakan penelitian eksperimen dengan menggunakan model pembelajaran kooperatif dengan tutor sebaya. Desain penelitian yang digunakan adalah One Group Prestest-Posttesst Design. Desain eksperimen dalam penelitian tersebut dapat digambarkan sebagai berikut:

Tabel 1. Desain Penelitian

\begin{tabular}{ccc}
\hline Pretes & Perlakuan & Posttest \\
\hline $\mathrm{O}_{1}$ & $\mathrm{X}$ & $\mathrm{O}_{2}$
\end{tabular}

Sumber: Sukardi, Tahun: 2010

Keterangan:

$\mathrm{O}_{1}=$ Pengukuran pertama sebelum subjek diberi perlakuan (pretest)

$\mathrm{X}=$ Treatment atau Perlakuan dengan mengunakan model pembelajaran perolehan konsep

$\mathrm{O}_{2}=$ Pengukuran kedua setelah subjek diberi perlakuan (posttest).

\section{Satuan Eksperimen}

Satuan eksperimen pada penelitian ini adalah mahasiswa semester VI Program Studi Pendidikan Matematika UNCP yang terdiri atas 6 kelas. Teknik pengambilan 
sampel yang digunakan adalah teknik sampel acak. Sampel dari penelitian ini adalah mahasiswa kelas 6A sebanyak 32 orang pada Program Studi Pendidikan Matematika UNCP Semester Genap Tahun Akademik 2015/2016.

\section{Instrumen Penelitian dan Teknik Pengumpulan Data}

Instrumen penelitian yang digunakan untuk memperoleh data dari penelitian ini adalah tes hasil belajar (THB) sesuai dengan materi yang telah dipelajari oleh mahasiswa, yang berbentuk uraian (tes essai). Tes hasil belajar ini digunakan untuk mengetahui seberapa besar hasil belajar mahasiswa program studi Pendidikan Matematika UNCP pada matakuliah analisis real sebelum dan setelah mengalami proses pembelajaran dalam jangka waktu tertentu pada kelas eksperimen tersebut. Instrumen tersebut dibuat sendiri oleh peneliti, namun dengan memperhatikan setiap indikator pencapaian yang ingin dicapai.

Data diperoleh dengan pemberian tes berupa tes urain pada mahasiswa kelas eksperimen sebelum diajar dengan menggunakan model pembelajaran kooperatif dengan tutor sebaya (pretest). Kemudian peneliti kembali memberikan tes (posttest) setelah memberikan perlakuan khusus yaitu diajar dengan menggunakan model pembelajaran kooperatif dengan tutor sebaya. Hasil tes inilah yang akan diolah dan analisis guna keperluan pengujian hipotesis yang telah dirumuskan.

\section{E. Teknik Analisis Data}

Teknik analisis data yang digunakan pada penelitian ini adalah analisis statistik deskriptif dan inferensial. Penelitian ini dianalisis dengan menggunakan program SPSS. Statistik inferensial digunakan untuk menguji hipotesis penelitian yaitu dengan uji $t$ (distribusi student $t$ ). Sebelum dilakukan pengujian hipotesis terlebih dahulu dilakukan uji normalitas dari data hasil belajar matematika mahasiswa. Data yang digunakan untuk uji- $t$ diambil dari skor gain ternormalisasi $\langle g\rangle$ yang dinyatakan oleh rumus berikut:

$$
<g>=\frac{\text { Skor posttest }- \text { Skor pretest }}{\text { Skor maksimal ideal - Skor pretest }}
$$

Hasil skor gain ternormalisasi dibagi ke dalam tiga kategori yang dapat dilihat pada tabel berikut:

Tabel 2. Klasifikasi Gain Ternormalisasi

\begin{tabular}{cc}
\hline Persentase & Klasifikasi \\
\hline$g<0.3$ & Rendah \\
\hline $0.3 \leq g<0.3$ & Sedang \\
\hline$g \geq 0.7$ & Tinggi \\
\hline Sumber: Redhana, Tahun: 2010 &
\end{tabular}

Sumber: Redhana, Tahun: 2010 
Untuk mengetahui hasil belajar matematika siswa digunakan kriteria sebagai berikut:

Tabel 3. Kriteria hasil belajar dan kategorinya.

\begin{tabular}{cc}
\hline Skor & Kategori \\
\hline $0-54$ & Sangat rendah \\
$55-64$ & Rendah \\
$65-79$ & Sedang \\
$80-89$ & Tinggi \\
$90-100$ & Sangat tinggi \\
\hline
\end{tabular}

Sumber : Nurkancana, Tahun: 2011

\section{HASIL DAN PEMBAHASAN}

Hasil analisis statistik deskriptif mahasiswa berdasarkan hasil tes awal (pretest) dan tes akhir (posttest) disajikan dalam Tabel 4 berikut:

Tabel 4. Statistik deskriptif hasil hasil tes awal (pretest) dan tes akhir (posttest)

\begin{tabular}{ccc}
\hline Statistik & Pretest & Posttest \\
\hline Rata-rata & 57,6562 & 78,875 \\
Deviasi Standar & 11,10248 & 10,80845 \\
Variansi & 123,265 & 116,8226 \\
Nilai terendah & 37 & 59 \\
Nilai tertinggi & 78 & 95 \\
\hline
\end{tabular}

Sumber: Data Primer, Tahun: 2016

Tabel 4. menunjukkan bahwa hasil belajar mahasiswa pada matakuliah analisis real setelah diterapkan model pembelajaran kooperatif dengan tutor sebaya mempunyai nilai lebih tinggi dari hasil belajar mahasiswa pada matakuliah analisis real sebelum diterapkan model pembelajaran kooperatif dengan tutor sebaya dengan nilai rata-rata posttest adalah 78,875 sedangkan nilai rata-rata pretest adalah 57,6562, deviasi standar 11.10, variansi 123.265 dengan nilai terendah 37 dan tertinggi 78 . Nilai minimum sebelum dan setelah diterapkan model pembelajaran kooperatif dengan tutor sebaya masing masing 37 dan 59, sedangkan nilai maksimum sebelum dan setelah diterapkan model pembelajaran kooperatif dengan tutor sebaya masing-masing 78 dan 95.

Jika data tersebut dikelompokkan kedalam lima kategori menurut maka diperoleh tabel distribusi frekuensi dan presentase hasil belajar matematika (pre-test) mahasiswa sebelum diterapkan model pembelajaran kooperatif dengan tutor sebaya sebagai berikut ini: 
Tabel 5. Distrbusi frekuensi dan presentase hasil belajar matematika (pre-test) mahasiswa sebelum diterapkan model pembelajaran kooperatif dengan tutor sebaya

\begin{tabular}{|c|c|c|c|}
\hline Skor & Kategori & Frekuensi & Presentase $(\%)$ \\
\hline $0-54$ & Sangat rendah & 11 & 34,375 \\
\hline $55-64$ & Rendah & 12 & 37,500 \\
\hline $65-79$ & Sedang & 9 & 28,125 \\
\hline $80-89$ & Tinggi & 0 & 0 \\
\hline $90-100$ & Sangat tinggi & 0 & 0 \\
\hline \multicolumn{2}{|c|}{ Jumlah } & 32 & 100 \\
\hline
\end{tabular}

Sumber: Data Primer, Tahun: 2016

Berdasarkan Tabel 5 terlihat bahwa 11 sampel (34,375\%) berada pada kategori sangat rendah, 12 sampel (37,5\%) berada pada kategori rendah dan 9 sampel $(28,125 \%)$ berada pada kategori sedang. Jadi, dapat disimpulkan bahwa hasil belajar mahasiswa semester VI Program Studi Pendidikan Matematika UNCP pada matakuliah analisis real sebelum diterapkan model pembelajaran kooperatif dengan totur sebaya berada pada kategori rendah.

Tabel distribusi frekuensi dan presentase hasil belajar matematika (posttest) mahasiswa setelah diterapkan model pembelajaran kooperatif dengan tutor sebaya sebagai berikut ini:

Tabel 6. Distribusi frekuensi dan presentase hasil belajar matematika (post-test) mahasiswa setelah diterapkan model pembelajaran kooperatif dengan tutor sebaya

\begin{tabular}{|c|c|c|c|}
\hline Skor & Kategori & Frekuensi & Presentase (\%) \\
\hline $0-54$ & Sangat rendah & 0 & 0 \\
\hline $55-64$ & Rendah & 4 & 12.5 \\
\hline $65-79$ & Sedang & 13 & 40.625 \\
\hline $80-89$ & Tinggi & 11 & 34.375 \\
\hline $90-100$ & Sangat tinggi & 4 & 12.5 \\
\hline
\end{tabular}

Sumber: Data Primer, Tahun: 2016

Berdasarkan Tabel 6. terlihat bahwa 4 sampel (12.5\%) pada kategori rendah, 13 sampel (40.625\%) pada kategori sedang, 11 sampel (34.375\%) pada kategori tinggi dan 4 sampel (12.5\%) pada kategori sangat tinggi. Jadi, dapat disimpulkan bahwa hasil belajar mahasiswa semester VI Program Studi Pendidikan Matematika UNCP pada matakuliah analisis real setelah diterapkan model pembelajaran kooperatif dengan totur sebaya berada pada kategori sedang.

Peningkatan hasil belajar dapat dilihat dengan melakukan analisis terhadap gain ternormalisasi. Adapun hasil analisis statistik deskriptif gain ternormalisasi disajikan pada 
Tabel 7. berikut:

Tabel 7. Statistik deskriptif gain ternormalisasi

\begin{tabular}{cc}
\hline Statistik & Nilai Statistik \\
\hline Ukuran sampel & 32 \\
Rata-rata & 0.513595 \\
Deviasi Standar & 0.212657 \\
Variansi & 0.045223 \\
Nilai terendah & 0.8333 \\
Nilai tertinggi & 0.02381 \\
\hline
\end{tabular}

Sumber: Data Primer, Tahun: 2016

Tabel 7. menunjukkan rata-rata gain kelas eksperimen adalah 0.514, standar deviasi 0.213 , variansi 0.045 dengan nilai terendah 0.0234 dan tertinggi 0.833 . Dari ratarata gain terlihat bahwa terjadi peningkatan hasil belajar sebelum dan setelah mahasiswa diajar dengan menggunakan model kooperatif dengan tutor sebaya. Peningkatan hasil belajar tersebut berada pada kategori sedang.

Sebelum dilakukan uji hipotesis terlebih dahulu dilakukan uji normalitas. Uji normalitas yang dilakukan dengan menggunakan uji Kolmogorov-Smirnov dengan taraf signifikansi 0,05 (5\%). Berdasarkan uji Kolmogorov-Smirnov diperoleh bahwa data hasil belajar pada matakuliah analisis real berdistribusi normal dengan dengan nilai signikansi yang lebih dari 0,05 yaitu $P$-value pretest sebesar 0,994 dan P-value posttest sebesar 0,450 .

Selanjutnya dilakukan uji hipotesis yaitu one sample t-test. Perhitungan uji $t$ terhadap gain hasil belajar dengan menggunakan SPSS diperoleh bahwa nilai signifikansi one sample t-test dari gain hasil belajar mahasiswa kurang dari 0.05 (0.0001). Artinya pada taraf signifikansi $5 \%$, hipotesis nol $\left(H_{0}\right)$ yang menyatakan bahwa rata-rata gain ternormalisasi hasil belajar analisis real mahasiswa Program Studi Pendidikan Matematika sebelum dan sesudah diterapkan model pembelajaran kooperatif dengan tutor sebaya kurang dari atau sama dengan 0.29 ditolak. Dengan demikian disimpulkan bahwa rata-rata gain ternormalisasi hasil belajar analisis real mahasiswa Program Studi Pendidikan Matematika sebelum dan sesudah diterapkan model pembelajaran kooperatif dengan tutor sebaya lebih dari atau sama dengan 0.3. Maka disimpulkan bahwa penggunaan model pembelajaran kooperatif dengan tutor sebaya berpengaruh terhadap hasil belajar mahasiswa pada matakuliah analisis real terbukti dengan adanya peningkatan hasil belajar analisis real mahasiswa program studi pendidikan matematika UNCP setelah diajar dengan rata-rata peningkatan 0.514 atau berada pada kategori sedang. 


\section{KESIMPULAN DAN SARAN}

\section{A. Kesimpulan}

Berdasarkan hasil dan pembahasan, diperoleh kesimpulan sebagai berikut:

1) Hasil belajar matematika mahasiswa semester VI Program Studi Pendidikan Matematika UNCP pada matakuliah analisis real mengalami peningkatan setelah diajar dengan model pembelajaran kooperatif tutor sebaya.

2) Peningkatan hasil belajar matematika mahasiswa semester VI Program Studi Pendidikan Matematika UNCP pada matakuliah analisis real dihitung dengan rumus gain ternormalisasi sebesar 0.514. Hal ini berarti, peningkatan motivasi belajar berada dalam kategori sedang.

3) Model pembelajaran kooperatif dengan tutor sebaya berpengaruh terhadap hasil belajar mahasiswa pada matakuliah analisis real.

B. Saran

Berdasarkan hasil penelitian dapat dikemukakan saran-saran sebagai berikut:

1) Bagi mahasiswa, hendaknya aktif dalam proses pembelajaran (perkuliahan)

2) Bagi dosen/tenaga pengajar harus lebih pandai memilih model, metode, strategi maupun media-media pembelajaran yang dapat meransang mahasiswa (peserta didik) untuk lebih aktif proses pembelajaran

3) Bagi peneliti yang berminat mengembangkan lebih lanjut penelitian ini, diharapkan melanjutkan variabel-variabel yang lebih bervariasi, mencermati kelemahankelemahan dan keterbatasan penelitian ini, sehingga penelitian selanjutnya dapat menyempunakan hasil penelitian ini 


\section{DAFTAR PUSTAKA}

Ahmadi, A dan Widodo S. (2013). Psikologi Belajar Edisi Revisi. Jakarta: Rineka Cipta.

Djamarah, S.B. dan Aswan Z. (2010). Strategi Belajar Mengajar. Jakarta: Rineka Cipta.

Fathurrahman, Pupuh dan Sobry Sutikno. (2007), Strategi Belajar Mengajar, Bandung: PT. Refika Aditama.

Mulyadi. (2008). Diagnosis Kesulitan Belajar dan Bimbingan terhadap Kesulitan Belajar Khusus, Malang: Nuha Litera

Nurkancana. (2011). Evaluasi Pendidikan. Surabaya: Usaha Nasional.

Rusman. (2010). Model-model Pembelajaran. Mengembangkan Profesionalisme Guru. Jakarta: Rajawali Press.

Siberman, Mel. (2007). Active Learning 101 Strategi Pembelajaran Aktif. (Terjemahan dari Active Learning: 101 Strategies to Teach Any Subject). Yogyakarta: Pustaka Insan Madani.

Sugiyono. (2013). Metode Penelitian Pendidikan Pendekatan Kuantitatif, Kualitatif, dan R\&D, Bandung: Alfabeta

Sukardi. (2010). Metodologi Penelitian Pendidikan. Jakarta: Bumi Aksara.

Suprijono, Agus.(2010). Cooperative Learning Teori dan Aplikasi PAIKEM. Yogyakarta : Pustaka Pelajar.

Trianto. (2011). Model-Model Pembelajaran Inovatif Berorientasi Konstruktivistik. Jakarta : Prestasi Pustaka 